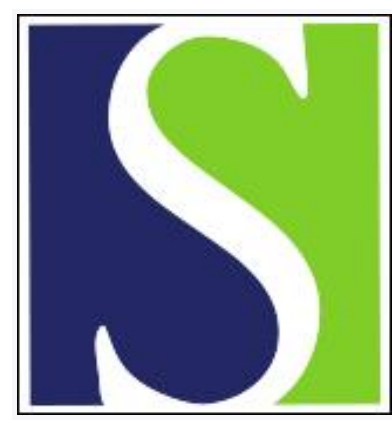

Scand J Work Environ Health 2000;26(6):514-522

https://doi.org/10.5271/sjweh.576

Issue date: Dec 2000

Changes in the ocular and nasal signs and symptoms of aircrews in relation to the ban on smoking on intercontinental flights

by Wieslander $G$, Lindgren T, Norbäck D, Venge $P$

The following article refers to this text: 2003;29(6):411-430

Key terms: acoustic rhinometry; aerospace medicine; environmental tobacco smoke; eosinophil cationic protein; lysozyme; myeloperoxidase; nasal congestion; ocular symptom; respirable particle; tear-film break up time

This article in PubMed: www.ncbi.nlm.nih.gov/pubmed/11201399

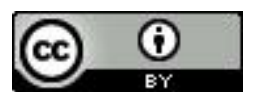




\title{
Changes in the ocular and nasal signs and symptoms of aircrews in relation to the ban on smoking on intercontinental flights
}

\author{
by Gunilla Wieslander, MD, ${ }^{1}$ Torsten Lindgren, BSc, ${ }^{1}$ Dan Norbäck, PhD, ${ }^{1}$ Per Venge, MD'
}

Wieslander G, Lindgren T, Norbäck D, Venge $P$. Changes in the ocular and nasal signs and symptoms of aircrews in relation to the ban on smoking on intercontinental flights. Scand J Work Environ Health 2000;26(6):514-522.

\begin{abstract}
Objectives This study determined the influence of exposure to environmental tobacco smoke (ETS) in aircraft on measured and perceived cabin air quality (CAQ), symptoms, tear-film stability, nasal patency, and biomarkers in nasal lavage fluid.

Methods Commercial aircrews underwent a standardized examination, including acoustic rhinometry, nasal lavage, and measurement of tear-film break-up time. Eosinophilic cationic protein, myeloperoxidase, lysozyme, and albumin were analyzed in the nasal lavage fluid. Inflight investigations [participation rate $98 \%(\mathrm{~N}=39)$ ] were performed on board 4 flights, 2 in each direction between Scandinavia and Japan. Scandinavian crew on 6 flights from Scandinavia to Japan participated in postflight measurements after landing [participation rate $85 \%(\mathrm{~N}=41)$ ]. Half the flights permitted smoking on board, and the other half, 0.5 months later, did not. Hygienic measurements showed low relative air humidity on board $(2-10 \%)$ and a carbon dioxide concentration of $<1000$ ppm during $99.6 \%$ of the cruising time.

Results The smoking ban caused a drastic reduction of respirable particles, from a mean of 66 (SD 56) $\mu \mathrm{g} / \mathrm{m}^{3}$ to 3 (SD 0.8) $\mu \mathrm{g} / \mathrm{m}^{3}$. The perceived CAQ was improved, and there were fewer symptoms, particularly ocular symptoms, headache and tiredness. Tear-film stability increased, and nasal patency was altered.

Conclusions Despite a high air exchange rate and spatial separation between smokers and nonsmokers, smoking in commercial aircraft may cause significant air pollution, as indicated by a large increase in respirable particles. This ETS exposure is associated with an increase in ocular and general symptoms, decreased tear-film stability, and alterations of nasal patency.
\end{abstract}

Key terms acoustic rhinometry, aerospace medicine, environmental tobacco smoke, eosinophilic cationic protein, lysozyme, myeloperoxidase, nasal congestion, ocular symptoms, respirable particles, tear-film break up time.

Discomfort and nonspecific symptomatology in relation to the indoor environment has been studied mainly among office workers $(1,2)$. Various factors, including high room temperature, low outdoor air supply flow rate, low air humidity, aerosol exposure, and formaldehyde have been found to increase the occurrence of irritative symptoms (1, 2). Environmental tobacco smoke (ETS) has been recognized as a significant indoor air pollutant with respect to lung cancer and cardiovascular disease (3). In addition, there are few epidemiologic studies on environmental tobacco smoke as a cause of irritative symptoms among office workers $(4,5)$. Moreover, ex- perimental studies have shown a decrease in nasal patency $(6,7)$ and alterations of human nasal mucociliary clearance after exposure to sidestream tobacco smoke (8).

There is little information available on subjective indoor air quality and symptoms in relation to indoor air pollution in the transport sector. The future growth of aircraft transportation is estimated to be $5 \%$ per year on a global basis (9), and worldwide nowadays more than 1000 million people are transported by aircraft annually (10). The cabin environment is characterized by low relative air humidity, typically between $5 \%$ and $25 \%(10$,

Department of Medical Sciences and Asthma Research Centre, Uppsala University, University Hospital, Uppsala, Sweden.

Reprint requests to: Dr Gunilla Wieslander, Department of Medical Sciences/Occupational and Environmental Medicine, University Hospital, SE-751 85 Uppsala, Sweden. [E-mail: gunilla.wieslander@medsci.uu.se] 
11). Moreover, the cabin in commercial aircraft is densely populated, and exposure to environmental tobacco smoke can occur if smoking is allowed $(10,12-18)$.

Previous questionnaire investigations of commercial aircrews (19-22) have found a high prevalence of eye, nose, and throat symptoms, typically $40-70 \%$. In 2 of the studies $(21,22)$, the symptoms were suspected to be caused by exposure to ozone during higher altitude flights. In addition, there has been concern about environmental tobacco smoke as a health hazard in aircraft $(10,12-18)$. Recently, many flight companies have prohibited smoking on board, but few hygienic or medical evaluations have been made of the ban on smoking in aircraft.

Recently, objective methods have been developed with which to study environmental effects on the upper airways and eyes (23-25). Acoustic rhinometry can be applied in field studies of nasal patency $(26,27)$. In addition nasal lavage is a well documented technique for studying inflammatory effects in the nasal mucosa in relation to inhalatory exposure (24-27). Experimental studies with nasal lavage have shown that a large number of possible biomarkers is available, including tryptase, albumin, lysozyme, eosinophil cationic protein emitted from the granula of activated eosinophilic granulocytes, and myeloperoxidase emitted from activated neutrophilic granulocytes $(24,25,28)$. In addition, measurements of objective signs from the eyes (eg, tear-film stability) can be applied (29-31). Recent epidemiologic studies have applied these objective methods $(26,27,29,31)$, but none have been used in studies on aircrews.

In this study our aim was to determine the influence of a ban on smoking on commercial airlines on measured and perceived cabin air quality, nonspecific symptomatology, tear-film stability, nasal patency, and selected biomarkers in nasal lavage fluid.

\section{Subjects and methods}

\section{Subjects of the inflight investigation}

The research team made 2 trips direct from Stockholm to Tokyo, and back, either via Copenhagen or directly to Stockholm. One trip was made at the end of August, just before inflight smoking was banned; the others took place in mid-September, 2 weeks after smoking was banned on all intercontinental flights. On each flight, there are always 2 Japanese attendants, 5 Scandinavian cabin attendants, and 3 Scandinavian pilots. All aircrew members on these 4 flights $(\mathrm{N}=40)$ were invited to participate in the medical investigations performed on board during the later part of the 11- to 12-hour flights, operated by the Scandinavian Airline System (SAS). Altogether, 39 out of $40(98 \%)$ answered the medical ques- tionnaire, and 37 (93\%) participated in the medical examinations. One Japanese crew member with asthma was excluded on a smoking flight when the examination was restricted to nonasthmatic subjects.

\section{Subjects of the postflight investigation}

To increase the study population, and to enable a comparison of the differences in clinical parameters after landing, postflight aircrews of 6 flights staying at the same crew hotel in Tokyo were examined postflight. Two of the flights had the same staff as in the inflight investigation, the other 4 were flights arriving on the same days as the flight used by the research team. The medical examinations were performed at the same crew hotel in central Tokyo, on the 12th floor of the hotel, mostly within 24 hours after the flight. Since the Japanese crew from each flight did not stay at the crew hotel, they were excluded from this part of the study. Altogether 41 of the 48 Scandinavian aircrew members $(85 \%)$ participated in the postflight investigation. One Scandinavian crew member with asthma, who worked on a smoking flight and participated only in the postflight investigations, was excluded when the examination was restricted to nonasthmatic subjects.

\section{Assessment of personal factors and symptoms}

The subjects were questioned by a physician about allergy and other diseases, medication, occupational data, smoking habits, and social status. Atopy was defined as a current history of allergic manifestations related to exposure to common allergens mediated by immunoglobulin (Ig) E in Sweden (tree pollen, grass pollen, or animal fur) reported in the medical interview. Information on current symptoms during flights was gathered by means of a self-administered questionnaire, given to the subjects by the physician at the time of the medical examination. The set of symptoms included questions on nasal symptoms, ocular symptoms, throat symptoms, dermal symptoms, dyspnea, and general symptoms. There was also a question about dyspnea during the flight. To avoid differences in pollen exposure in Scandinavia between smoking and nonsmoking flights, the examinations were performed at the end of August and in mid-September, an off-pollen season.

Altogether, 51 aircrew members participated in the study, either in the inflight or the postflight investigation. Of these persons, one-third consisted of pilots. All the pilots were men, about one-fourth of all the participants were current smokers, and about 1 out of 7 had a history of atopy. Frequent sinusitis was common, reported by $25 \%$ of all the participants. None of the participants used contact lenses during flights. One crew 
Table 1. Selected medical and occupational data for the aircrewa before and after the smoking ban.

\begin{tabular}{lcc}
\hline Characteristics & $\begin{array}{c}\text { Before ban } \\
(\mathrm{N}=27) \\
(\%)\end{array}$ & $\begin{array}{l}\text { After ban } \\
(\mathrm{N}=24) \\
(\%)\end{array}$ \\
\hline Female & 35 & 41 \\
Doctor's diagnosed asthma & 8 & 0 \\
Current tobacco smoker & 27 & 21 \\
Atopyb & 11 & 21 \\
Cabin crew & 72 & 71 \\
Pilots & 28 & 29 \\
\hline
\end{tabular}

a Participating either in the inflight or the postflight investigation.

bCurrent allergy to tree pollen, grass pollen or animal fur.

member participating in the inflight investigation only and another participating in the postflight investigation only were asthmatics who had been diagnosed by a physician. Both were on smoking flights, none from the nonsmoking flights had asthma. The personal characteristics of the crews on smoking flights were similar to those of the nonsmoking flight crews (table 1). The protocol of the study was approved by the Ethical Committee of the Medical Faculty of the Uppsala University.

\section{Aircraft characterization}

The same type of major intercontinental aircraft (Boeing 767 -300) with a total number of 190 seats was used on all the flights. The smoking seats in the tourist class (rows $21-39$ ) were located near the aft galley, and smokers in the Euroclass (rows $1-17$ ) were located near the middle section.

The aircraft had a cabin volume of $428 \mathrm{~m}^{3}$, and a calculated ventilation capacity of $1320 \mathrm{l} / \mathrm{second}$ (32). The ventilation system normally provided approximately $50 \%$ fresh air and $50 \%$ recirculated air to the passenger cabin. Normally, the airflow rate should have provided about 7 turnovers per hour of fresh air to the cabin, or about 10 liters of outdoor air per passenger per second from the outside and the same flow of recirculated air in the passenger cabin. Occasionally, the pilot can shut off the recirculation fans for short periods, the result being a $100 \%$ fresh air supply and a 2-fold increase in the outdoor airflow. The air exchange rate on the flight deck is about 60 turnovers per hour. The engines in the flight supply the fresh air, passing through heated zones in the engine $\left(400^{\circ} \mathrm{C}\right)$. The air is conditioned by the air-conditioning packs, and ozone is removed as the fresh air passes through a catalytic ozone converter. The cabin air circulation system utilizes a prefilter for larger particles, a high-efficiency particulate air filter (HEPA) capturing particles equal or greater than $0.3 \mu \mathrm{m}$ with $99.99 \%$ efficiency, and a charcoal filter to remove volatile compounds. The air-conditioning system does not contain any air humidification devices.

\section{Methods to measure climate and air pollution in the cabin and at the crew hotel}

Inflight measurements were performed simultaneously with the medical examinations on board. The measurements included temperature, relative air humidity, concentration of respirable particles in the air, carbon dioxide $\left(\mathrm{CO}_{2}\right)$, airborne molds and bacteria, ozone, and formaldehyde. Volatile organic compounds (VOC) were measured, but the results will be reported in a separate publication. In addition, room temperature, relative air humidity, respirable particles, airborne molds and bacteria, ozone, and formaldehyde were measured in the room in which the postflight medical examinations took place at the crew hotel.

Inflight temperature and air humidity were recorded with a SWEMA logger 15 (SWEMA AB, Sweden), which sampled 1-minute average values. The logger was calibrated at the factory in connection with the investigation. Concentrations of respirable particles were measured by a direct-reading instrument, based on light scattering (Sibata P-5H2, Sibata Scientific Technology Ltd, Japan), that had been used in earlier indoor air investigations (33). The $\mathrm{CO}_{2}$ concentration was measured by a direct-reading infrared spectrometer (Rieken RI-411A, Rieken Keini, Japan), calibrated by standard gases containing known concentrations of $\mathrm{CO}_{2}$. The signal from the dust monitor and the $\mathrm{CO}_{2}$ meter were also recorded with the SWEMA logger, which sampled 1-minute average values. Moreover, short-term measurements of temperature and air humidity were done manually by an Assman psychrometer, and 15-minute average values of respirable particles were recorded during the medical investigation.

Airborne microorganisms were sampled on $25-\mathrm{mm}$ nucleopore filters with a pore size of $0.4 \mu \mathrm{m}$ and a sampling rate of $1.5 \mathrm{l} / \mathrm{minute}$ for 4 hours. The total concentrations of airborne molds and bacteria were determined by the CAMNEA method (34). Viable molds and bacteria were determined by incubation on 2 different media. The detection limit for viable organisms was 30 colonyforming units (cfu) per cubic meter of air. Ozone was measured with another diffusion sampler from the Swedish Environmental Research Institute, Sweden (35). To achieve sufficient detection limits, the sampling time was expanded to 16 hours, by sampling during 2 flights on the same sampler. The concentration of formaldehyde was measured with glass-fiber filters impregnated with 2,4-dinitro-phenylhydrazine (36), the air sampling rate being $0.21 /$ minute for 4 hours. The filters were analyzed by liquid chromatography.

\section{Indoor climate and air pollution in the aircraft}

When the medical examinations were made, the mean room temperature in the forward galley was $23.1^{\circ} \mathrm{C}$ dur- 
Table 2. Continuous 1-minute inflight measurements of cabin climate in the aft and forward galleys.

\begin{tabular}{|c|c|c|c|c|c|c|c|c|c|c|c|c|}
\hline \multirow[b]{2}{*}{ Location } & \multicolumn{4}{|c|}{ Temperature $\left({ }^{\circ} \mathrm{C}\right)$} & \multicolumn{4}{|c|}{ Relative humidity (\%) } & \multicolumn{4}{|c|}{ Carbon dioxide (ppm) } \\
\hline & $\mathrm{Na}^{\mathrm{a}}$ & Mean & $\mathrm{SD}$ & Range & $\mathrm{N}^{\mathrm{a}}$ & Mean & $\mathrm{SD}$ & Range & $\mathrm{N}^{\mathrm{a}}$ & Mean & SD & Range \\
\hline $\begin{array}{l}\text { Aft galley } \\
\text { Forward galley }\end{array}$ & $\begin{array}{r}1403 \\
327\end{array}$ & $\begin{array}{l}22.2 \\
23.0\end{array}$ & $\begin{array}{l}0.9 \\
0.2\end{array}$ & $\begin{array}{l}20.6-25.4 \\
22.3-23.3\end{array}$ & $\begin{array}{l}908 \\
327\end{array}$ & $\begin{array}{l}6.4 \\
3.8\end{array}$ & $\begin{array}{l}3.5 \\
1.8\end{array}$ & $\begin{array}{l}2.2-18.9 \\
1.8-8.7\end{array}$ & $\begin{array}{r}1250 \\
312\end{array}$ & $\begin{array}{l}570 \\
520\end{array}$ & $\begin{array}{l}147 \\
128\end{array}$ & $\begin{array}{l}360-1160 \\
370-1190\end{array}$ \\
\hline
\end{tabular}

${ }^{a} \mathrm{~N}=$ number of 1-minute measurements.

ing the smoking flights and $23.0^{\circ} \mathrm{C}$ during the nonsmoking flights. In the aft galley, the room temperature was $21.7^{\circ} \mathrm{C}$ during the smoking flights and $22.1^{\circ} \mathrm{C}$ during the nonsmoking flights, a nonsignificant difference. The results of the $\mathrm{CO}_{2}$ measurements were below the recommended Swedish ventilation standard of $1000 \mathrm{ppm}$ (37) in $99.6 \%$ of all the measurements, with no significant differences in the mean $\mathrm{CO}_{2}$ levels between the smoking and nonsmoking flights. The mean values for all the flights are given in table 2 .

There were striking differences in the concentration of respirable particles, in relation to smoking on board. The mean concentration of respirable particles was $66 \mu \mathrm{g} / \mathrm{m}^{3}$ for the aft galley, with a maximum value of $253 \mu \mathrm{g} / \mathrm{m}^{3}$ during smoke conditions. The corresponding values during nonsmoke conditions were $3 \mu \mathrm{g} / \mathrm{m}^{3}$ for the aft galley, with a maximum value of $7 \mu \mathrm{g} / \mathrm{m}^{3}(\mathrm{P}<0.001)$ (table 3 ). Respirable particles in the forward galley were measured only during nonsmoke conditions, but the results were similar to those of the aft galley, after the ban on smoking (table 3).

The average ozone concentration during all flights was $13.5 \mu \mathrm{g} / \mathrm{m}^{3}$ in the aft galley, $32.5 \mu \mathrm{g} / \mathrm{m}^{3}$ in the forward galley, and $60.9 \mu \mathrm{g} / \mathrm{m}^{3}$ in the cockpit. The concentration of formaldehyde, in both the forward and aft gallies was below the detection limit $\left(<5 \mu \mathrm{g} / \mathrm{m}^{3}\right)$ during all the flights, irrespective of the smoke or nonsmoke conditions. The concentrations of viable molds and bacteria, as well as the total mold and bacteria concentrations, were measured on 1 flight after the smoking ban. In the aft galley, neither air concentrations of viable molds or bacteria $\left(<100 \mathrm{cfu} / \mathrm{m}^{3}\right)$ nor total concentrations of molds or bacteria $\left(<10000\right.$ organisms $\left./ \mathrm{m}^{3}\right)$ could be detected. In the forward galley, there were no detectable air concentrations of viable molds $\left(<100 \mathrm{cfu} / \mathrm{m}^{3}\right)$, a low concentration of viable bacteria $\left(140 \mathrm{cfu} / \mathrm{m}^{3}\right)$, and no detectable total mold or bacteria concentration $(<10000$ organisms $/ \mathrm{m}^{3}$ ) was found. No viable species could be identified for any sample during the cultivation.

\section{Indoor climate and air pollution at the crew hotel}

The average room temperature in the examination room was $23.4^{\circ} \mathrm{C}$ in August 1997 after the smoking flights and $23.9^{\circ} \mathrm{C}$ in September 1997 after the nonsmoking flights, the difference being nonsignificant. The average relative air humidity in the hotel room was $65 \%$ in both August and September. The concentration in the air of the hotel
Table 3. Respirable particle concentrations before and after the ban on smoking.

\begin{tabular}{lrrrr}
\hline & \multicolumn{4}{c}{ Respirable particle concentration } \\
\cline { 3 - 5 } & $\mathrm{Na}$ & Mean & SD & Range \\
\cline { 2 - 5 } & & & & \\
Aft galley & & & \\
Before ban & 847 & 66 & 56 & $<1-253$ \\
$\begin{array}{l}\text { After ban } \\
\text { Forward galley } \\
\text { After ban }\end{array}$ & 566 & 3 & 0.8 & $<1-7$ \\
\hline
\end{tabular}

room was $12 \mu \mathrm{g} / \mathrm{m}^{3}$ for respirable particles, $5 \mu \mathrm{g} / \mathrm{m}^{3}$ for formaldehyde, and $5.5 \mu \mathrm{g} / \mathrm{m}^{3}$ for ozone. No detectable air concentrations of viable molds were found in the hotel $\left(<100 \mathrm{cfu} / \mathrm{m}^{3}\right)$, the concentration of viable bacteria was low $(110 \mathrm{cfu} / \mathrm{m} 3)$, and there was no detectable total mold concentration $\left(<10000\right.$ organisms $\left./ \mathrm{m}^{3}\right)$ and a low concentration of total bacteria ( 12000 organisms $/ \mathrm{m}^{3}$ ). No viable species of molds or bacteria could be identified.

\section{Acoustic rhinometry}

Acoustic rhinometry (Rhin 2000, SR Electronics, Denmark; wideband noise; continuously transmitted) was performed at the end of the flight. The measurements were made according to standardized forms (sitting), after 5 minutes of rest, and prior to the lavage $(26,27)$. By means of acoustic reflection the minimal cross-sectional areas (MCA) on each side of the nose were measured from 0 to $22 \mathrm{~mm}$ (MCA1) and from 23 to $54 \mathrm{~mm}$ (MCA2) from the nasal opening. The volumes of the nasal cavity on the right and left sides were also measured from 0 to $22 \mathrm{~mm}$ (Vol1) and from 23 to $54 \mathrm{~mm}$ (Vol2). The mean values were calculated from 3 subsequent measurements on each side of the nose, and the data on nasal dimensions are presented as the sum of the values from the right and left sides.

\section{Nasal lavage}

Lavage of the nasal mucosa was made with a $20-\mathrm{ml}$ plastic syringe attached to a nose olive. The subjects were standing, with their head flexed about 30 degrees forward $(26,27)$. Room-temperature $\left(20-22^{\circ} \mathrm{C}\right)$, sterile $0.9 \%$ saline solution was introduced into the nasal cavity. Each nostril was lavaged with a $5-\mathrm{ml}$ solution that was flushed back and forth 5 times via the syringe, at an interval of a few seconds. The fluid was transferred to a $10-\mathrm{ml}$ 
polypropylene centrifuge tube. It was kept on ice, and within 300 minutes the solution was centrifuged at 800 $g$ for 5 minutes. The supernatant was recentrifuged at $1400 \mathrm{~g}$ for 5 minutes and immediately frozen to $-20^{\circ} \mathrm{C}$. Lysozyme was analyzed by means of radioimmunoassay (38). Eosinophil cationic protein and myeloperoxidase were measured by means of a double antibody radioimmunoassay method (Pharmacia Diagnostics AB, Uppsala, Sweden) $(39,40)$. The intra- and interassay variation coefficients for all 3 tests were less than $11 \%$. Albumin was measured by rate nephelometry on an array protein system (Beckman Instruments Inc).

\section{Tear-film stability}

Tear-film break-up time was estimated by a standardized method, self-reported break-up time, or break-up times measuring the time the subjects could keep their eyes

Table 4. Point prevalence of different symptoms among the nonasthmatic aircrew during the flights before and after the ban on smoking.

\begin{tabular}{lcc}
\hline Symptom & $\begin{array}{c}\text { Before ban } \\
(\mathrm{N}=19) \\
(\%)\end{array}$ & $\begin{array}{c}\text { After ban } \\
(\mathrm{N}=19) \\
(\%)\end{array}$ \\
\hline Burning eyes & 25 & 11 \\
Itching eyes & 35 & 11 \\
Dry eyes & 55 & 42 \\
Sore eyes & 30 & 5 \\
Eye redness & 35 & 0 \\
Swollen eyelids & 10 & 0 \\
Runny nose & 25 & 11 \\
Nasal itching & 10 & 5 \\
Sneezing & 10 & 5 \\
Nasal obstruction & 25 & 21 \\
Dryness in the throat & 30 & 21 \\
Sore throat & 15 & 0 \\
Irritative cough & 15 & 0 \\
Headache & 10 & 0 \\
Tiredness & 25 & 0 \\
Sensation of getting a cold & 20 & 0 \\
Nausea & 10 & 0 \\
Facial itching & 5 & 5 \\
Facial rash & 0 & 5 \\
\hline
\end{tabular}

Table 5. Proportion of nonasthmatic aircrew with different symptoms during the flights before and after the ban on smoking.

\begin{tabular}{lccl}
\hline $\begin{array}{l}\text { Symptom } \\
\text { category }\end{array}$ & $\begin{array}{l}\text { Before ban } \\
(N=19) \\
(\%)^{\mathrm{a}}\end{array}$ & $\begin{array}{l}\text { After ban } \\
(\mathrm{N}=19) \\
(\%)^{\mathrm{a}}\end{array}$ & P-valueb $^{\mathrm{b}}$ \\
\hline Eye $^{\mathrm{N}}$ & 55 & 11 & 0.004 \\
Thasal $^{\mathrm{d}}$ & 20 & 5 & 0.19 \\
Generat $^{\mathrm{a}}$ & 20 & 0 & 0.06 \\
Facial sking $^{\mathrm{f}}$ & 15 & 0 & 0.13 \\
\hline
\end{tabular}

a Proportion of subjects with $>1$ symptom in each category.

- Difference before and after ban, calculated by Fisher's exact test.

'Burning, itching, dry, or sore eyes, eye redness, or swollen eyelids.

dRunny nose, nasal itching, sneezing, or nasal obstruction.

eThroat dryness, sore throat, or irritative cough.

Headache, tiredness, nausea, or sensation of getting a cold.

${ }_{9}$ Facial rash or facial itching. open without pain when watching a fixed point on the wall. The method has been used previously in field studies $(27,31)$, and its results have been shown to correlate well with those of the fluoresceine method for detecting tear-film break-up time $(31,41)$.

\section{Statistical analyses}

Differences in the dichotomous personal characteristics and symptoms between the aircrews of the smoking and nonsmoking flights were analyzed by Fishers' exact test. The differences in age, total symptom index, and all types of clinical signs were tested by the Mann-Whitney Utest. The differences in the average values from the 1minute measurements of the cabin climate and the respirable dust concentrations between the smoking and nonsmoking flights were analyzed by Student's t-test. In all the statistical analyses, 2-tailed tests and a 5\% level of significance were used.

\section{Results}

\section{Symptoms and subjective cabin air quality in relation to inflight exposure to environmental tobacco smoke}

In all the statistical analyses, the 2 subjects with asthma from the smoking flights were excluded. A numerical decrease of all types of individual symptoms, except facial dermal symptoms, occurred for the nonasthmatic subjects after the smoking ban (table 4). When the material was dichotomized with respect to the occurrence of more than 1 symptom in each symptom category, the occurrence of more than 1 ocular symptom was decreased from $55 \%$ to $11 \%(\mathrm{P}=0.004)$ after the smoking ban (table 5). In addition, the total symptom score was higher for the smoke conditions (mean 3.9, SD 4.0) than for the nonsmoke conditions (mean 1.4, SD 1.6) $(\mathrm{P}=0.05)$. The symptom improvement was the most pronounced for the general symptoms. Before the smoking ban, $35 \%$ of the crew reported at least 1 general symptom (headache, fatigue, nausea, sensation of catching a cold). After the ban, none reported any of these symptoms ( $\mathrm{P}=0.005$ by Fisher's exact test). In addition, the perception of the cabin air quality was improved after the ban $(\mathrm{P}=0.03)$, while the ratings for perceived air humidity and dustiness remained unchanged (table 6).

\section{Physiological signs in relation to exposure to environmental tobacco smoke}

The measurement of tear-film stability during the flights showed a significantly increased stability after the smoking ban ( $\mathrm{P}=0.01)$, with a mean of 25 seconds as compared with 10 seconds. There were also alterations in nasal patency in relation to the smoking ban. Rhinometric measurements on board showed a greater posterior 
nasal cross-sectional area (MCA2) during the smoking flights than during the nonsmoke conditions ( $\mathrm{P}=0.05)$, but no significant differences for the other nasal dimensions (MCA1, Vol1, Vol2) were found (table 7).

Postflight measurements in the hotel showed a numerical but insignificant increase in tear-film stability after the smoking ban (a mean of 42 seconds as compared with 25 seconds). The rhinometric measurements at the hotel showed a numerically greater nasal patency for all 4 parameters after the nonsmoking flights, statistically significant for anterior nasal volume (Vol1) $(\mathrm{P}=0.03)(\mathrm{ta}-$ ble 7).

Nasal lavage, performed at the crew hotel, showed no significant effects of smoking on board. The median concentration of eosinophil cationic protein was similar during both conditions [median 1.0 (interquartile range $<1-1.2) \mu \mathrm{g} / 1]$. The median concentrations of myeloperoxidase and albumin were similar and below the detection limits $(<4 \mu \mathrm{g} / 1$ and $<2 \mathrm{mg} / 1$, respectively) both before and after the smoking ban. The lysozyme concentration in the nasal lavage fluid was numerically higher for the smoke conditions [median 0.26 (interquartile range $0.13-0.45) \mathrm{mg} / \mathrm{l}]$ than the nonsmoke conditions [median 0.17 (interquartile range $0.13-0.45$ ) $\mathrm{mg} / \mathrm{l}$ ].

\section{Discussion}

Our study showed that exposure to environmental tobacco smoke in commercial aircraft may impair cabin air quality and increase exposure to respirable particles with an order of magnitude of $>1$. We also showed that exposure to environmental tobacco smoke affects aircrews, there being an increase in irritative symptoms, impaired perceived cabin air quality, decreased tear-film stability, and alterations in nasal patency. To our knowledge, this is the first publication on the hygienic and physiological effects of the ban on smoking in commercial aircraft.

The study was interventional, but, since the aircrew changes from flight to flight, none of the participants appeared more than once in the investigation. Selection bias due to low response rate was less likely since the participation rate was relatively high, $85 \%$ in the postflight clinical examination and $98 \%$ in the study on board. Moreover, the participants on board during the smoking and nonsmoking conditions were comparable with respect to mean age, gender, tobacco smoking, atopy, and occupation. The aircraft were the same, seasonal variation between smoking flights and nonsmoking flights should be negligible, the medical investigations were standardized, and all samples from the nasal lavage were run in the same batch. It could be possible that smokers would avoid flying on nonsmoking flights, due to withdrawal symptoms. However, in our study, no significant difference in the proportion of smokers was observed between the smoking and nonsmoking flights. It could also be possible that sensitive staff, not able to stand exposure to environmental tobacco smoke during smoking flights, would start flying on intercontinental flights after the ban on smoking. We had 2 asthmatics in the crew during the smoking flights and none during the

Table 6. Perceived cabin air quality during the flights as reported by the nonasthmatic aircrew before and after the ban on smoking.

\begin{tabular}{|c|c|c|c|c|c|c|c|}
\hline & \multirow[t]{2}{*}{$\mathrm{Na}$} & \multicolumn{2}{|c|}{$\begin{array}{l}\text { Air quality } \\
(0-100 \%)\end{array}$} & \multicolumn{2}{|c|}{$\begin{array}{l}\text { Air humidity } \\
(0-100 \%)\end{array}$} & \multicolumn{2}{|c|}{$\begin{array}{l}\text { Dustiness of the air } \\
\qquad(0-100 \%)\end{array}$} \\
\hline & & Mean & SD & Mean & SD & Mean & SD \\
\hline $\begin{array}{l}\text { Before ban } \\
\text { After ban }\end{array}$ & $\begin{array}{l}19 \\
19\end{array}$ & $\begin{array}{l}36 \\
52\end{array}$ & $\begin{array}{l}21 \\
26\end{array}$ & $\begin{array}{c}17 \\
16\end{array}$ & $\begin{array}{l}18 \\
14\end{array}$ & $\begin{array}{l}56 \\
49\end{array}$ & $\begin{array}{l}29 \\
25\end{array}$ \\
\hline P-valuea & & \multicolumn{2}{|c|}{0.03} & \multicolumn{2}{|c|}{0.18} & \multicolumn{2}{|c|}{0.47} \\
\hline
\end{tabular}

a Number of subjects.

b Difference before and after the ban on smoking, calculated by the Mann-Whitney U-test.

Table 7. Tear-film stability and nasal patency of the nonasthmatic aircrew before and after the ban on smoking. (BUT=break-up time, $M C A 1=$ minimal cross-sectional area $0-22 \mathrm{~mm}, M C A 2=$ minimal cross-sectional area $23-54 \mathrm{~mm}$, vol1 = volume of nasal cavity $0-$ $22 \mathrm{~mm}$, Vol2 = volume of nasal cavity $23-54 \mathrm{~mm}$ )

\begin{tabular}{|c|c|c|c|c|c|c|c|c|c|c|c|}
\hline & \multirow[t]{2}{*}{$N^{a}$} & \multicolumn{2}{|c|}{ BUT (s) } & \multicolumn{2}{|c|}{$\operatorname{MCA1}\left(\mathrm{cm}^{2}\right)$} & \multicolumn{2}{|c|}{$\operatorname{MCA} 2\left(\mathrm{~cm}^{2}\right)$} & \multicolumn{2}{|c|}{ Vol1 $\left(\mathrm{cm}^{3}\right)$} & \multicolumn{2}{|c|}{ Vol2 $\left(\mathrm{cm}^{3}\right)$} \\
\hline & & Mean & $S D$ & Mean & SD & Mean & SD & Mean & SD & Mean & $\mathrm{SD}$ \\
\hline \multicolumn{12}{|c|}{ During flight in the aircraft } \\
\hline $\begin{array}{l}\text { Before ban } \\
\text { After ban }\end{array}$ & $\begin{array}{l}17 \\
19\end{array}$ & $\begin{array}{l}10 \\
25\end{array}$ & $\begin{array}{l}8.7 \\
31\end{array}$ & $\begin{array}{l}1.33 \\
1.35\end{array}$ & $\begin{array}{l}0.19 \\
0.37\end{array}$ & $\begin{array}{l}1.52 \\
1.22\end{array}$ & $\begin{array}{l}0.45 \\
0.37\end{array}$ & $\begin{array}{l}3.88 \\
4.13\end{array}$ & $\begin{array}{l}0.56 \\
0.83\end{array}$ & $\begin{array}{l}8.98 \\
8.81\end{array}$ & $\begin{array}{l}2.56 \\
2.59\end{array}$ \\
\hline P-value ${ }^{a}$ & & \multicolumn{2}{|c|}{0.01} & \multicolumn{2}{|c|}{0.45} & \multicolumn{2}{|c|}{0.05} & \multicolumn{2}{|c|}{0.33} & \multicolumn{2}{|c|}{0.49} \\
\hline \multicolumn{12}{|c|}{ After flight at the crew hotel } \\
\hline $\begin{array}{l}\text { Before ban } \\
\text { After ban }\end{array}$ & $\begin{array}{l}20 \\
20\end{array}$ & $\begin{array}{l}25 \\
42\end{array}$ & $\begin{array}{l}26 \\
50\end{array}$ & $\begin{array}{l}1.30 \\
1.32\end{array}$ & $\begin{array}{l}0.21 \\
0.36\end{array}$ & $\begin{array}{l}1.35 \\
1.39\end{array}$ & $\begin{array}{l}0.41 \\
0.37\end{array}$ & $\begin{array}{l}3.86 \\
4.41\end{array}$ & $\begin{array}{l}0.51 \\
0.84\end{array}$ & $\begin{array}{r}8.90 \\
10.02\end{array}$ & $\begin{array}{l}2.26 \\
3.07\end{array}$ \\
\hline P-value & & \multicolumn{2}{|c|}{0.26} & \multicolumn{2}{|c|}{0.46} & \multicolumn{2}{|c|}{0.49} & \multicolumn{2}{|c|}{0.03} & \multicolumn{2}{|c|}{0.23} \\
\hline
\end{tabular}

$\mathrm{N}=$ number of subjects.

bifference before and after the ban on smoking, calculated by the Mann-Whitney U-test. 
nonsmoking flights. Since the numerical differences in asthmatics between the groups could have biased the results of a small study, further statistical analysis was restricted to nonasthmatic aircrew members. Recall bias due to an awareness of exposure may affect symptom reporting, but it is unlikely to affect physiological signs. Thus we do not believe that our conclusions have been seriously biased by selection or response errors, or due to chance findings. In addition, the possibility that the observed relationships could be explained by some factor other than the exposure to environmental tobacco smoke on board the flights is less likely.

We found that irritative symptoms of different types were common among aircrews, but less common in the absence of environmental tobacco smoke. Even a higher symptom prevalence has been reported in earlier studies on aircraft crew. These studies were performed during previous decades, when ozone exposure could have been a major problem. We carried out a study on an aircraft (Boeing 767-300) with ozone converters, and we found low mean ozone levels in the cabin. In a North American survey of 744 flight attendants, 95\% reported eye discomfort in aircraft (19). In another American study on 1330 flight attendants, $60 \%$ reported eye problems, $75 \%$ reported sore or dry throat, and $16 \%$ reported nose bleeding (21). A high prevalence of nasal and ocular symptoms $(43-74 \%)$ was also reported in another American study (22). In a subsequent study on 1240 Norwegian aircrew members employed by the Scandinavian Airlines System (SAS), 53\% reported eye irritation, $44 \%$ complained of nasal congestion, and $26 \%$ had sinusitis (20).

Despite the efficient air filtration system, there was a striking effect of smoking on the concentration of respirable dust. We found an average concentration of 66 $\mu \mathrm{g} / \mathrm{m}^{3}$ of respirable particles, with maximum values up to $253 \mu \mathrm{g} / \mathrm{m}^{3}$, in the aft galley during smoke conditions. The smoking ban reduced the mean concentration to 4 $\mu \mathrm{g} / \mathrm{m}^{3}$ in the forward galley and to $3 \mu \mathrm{g} / \mathrm{m}^{3}$ in aft galley. The respirable particle concentrations in the aircraft after the ban were lower than in the hotel room in Tokyo $\left(12 \mu \mathrm{g} / \mathrm{m}^{3}\right)$ and lower than the mean concentration in Swedish dwellings $\left(19 \mu \mathrm{g} / \mathrm{m}^{3}\right)$, measured by the same instrumentation (42). Smokers and nonsmokers are separated in both Euroclass and tourist class. Since smokers in tourist class are seated next to the aft galley, environmental tobacco smoke is obviously transported into the aft galley. We have recently showed significant exposure to environmental tobacco smoke, through the detection of cotinine in urine, among aircrews working in the aft galley, while those working in the forward galley had no significant decrease of cotinine in urine after intercontinental flights in a Boeing 767-300 (15). The results of earlier studies, mainly focusing on passengers' exposure to environmental tobacco smoke, have resembled the results of our study, smoking flights having 5- to 20-fold higher levels of respirable suspendable particles at passengers' seats during smoking flights than during nonsmoking flights $(12,14,17)$.

We found that environmental tobacco smoke in aircraft decreases the preceived cabin air quality and increases the occurrence of symptoms, particularly eye symptoms, headache, and tiredness. There was a significantly increased tear-film stability after the cessation of smoking, from a mean value of 10 seconds to $25 \mathrm{sec}$ onds. Despite the low relative air humidity on board, tearfilm stability after the smoking ban was numerically higher among the flight crew than among office workers (median 17 seconds), when measured by the same method (27), and it partly normalized after landing.

The rhinometric data suggested alterations of nasal patency in relation to exposure to environmental tobacco smoke on board, with an acute decongestive effect of such smoke in aircraft, followed by a congestive rebound effect after landing. The explanation for this finding is unclear, but it could be a combined effect of environmental tobacco smoke and lower air humidity, temperature, and air pressure in the aircraft as compared with the hotel conditions. In other studies performed during normal pressure and higher relative air humidity $(40-42 \%)$ an acute congestive effect of environmental tobacco smoke was observed $(6,7)$.

Nasal lavage, performed only in the postflight investigation at the crew hotel, showed no significant effects of smoking on board. For practical reasons, the nasal lavage was not performed directly after landing, and therefore transient nasal effects could have been missed. Median lavage fluid concentrations of biomarkers in the aircrew members, irrespective of the presence or absence of environmental tobacco smoke, were only $30-70 \%$ of the mean values reported for 83 office workers in midSweden. This study used the same nasal lavage technique, and the same clinical laboratory, as for our aircrew investigation. For office workers, the median concentrations of eosinophil cationic protein, myeloperoxidase, lysozyme, and albumin were $1.4 \mu \mathrm{g} / \mathrm{l}, 5.5 \mu \mathrm{g} / \mathrm{l}$, $0.70 \mathrm{mg} / \mathrm{l}$, and $<2 \mathrm{mg} / \mathrm{l}$, respectively (27).

The relative air humidity was very low in both the aft and forward galleys (2-10\%), much lower than the relative air humidity indoors $(33-75 \%)$ in mid-Swedish dwellings during the heating season (43). Other studies have also found low relative air humidity in aircraft, typically $5-49 \%(10,11,44)$, but not as low as our values, measured during cruising at a high altitude (33-37000 feet; $10-112776$ meters), near the North Pole with extremely low outdoor humidity.

In addition to the high levels of respirable particles during smoke conditions and the low relative air humidity, other exposure measurements showed low or normal values. The concentration of molds and bacteria was low both in the aircraft and at the hotel, less than $10 \%$ of av- 
erage levels of molds and bacteria measured in Swedish dwellings, measured by the same method (43). Other investigators, using different methods to measure microbial contamination, have reported similar findings $(12,45)$. We found that the $\mathrm{CO}_{2}$ concentration on board, an indicator of the outdoor air supply rate, was generally between 500 and $700 \mathrm{ppm}$. Only $0.3 \%$ of the measured 1 minute values were above the current Swedish ventilation standard of $1000 \mathrm{ppm}$ (37). The low concentration of $\mathrm{CO}_{2}$ and microorganisms illustrates that the air filtration and ventilation systems had sufficient efficiency in the particular type of aircraft used. Other investigators have reported higher values, with average concentrations of $785-1756 \mathrm{ppm}$ of $\mathrm{CO}_{2}$ and $25-87 \%$ of all measurements above $1000 \mathrm{ppm}(32)$.

We found no formaldehyde $\left(<6 \mu \mathrm{g} / \mathrm{m}^{3}\right)$ on either type of flight. Eatough et al (14) reported higher values of formaldehyde [mean 25 (maximum 82) $\mu \mathrm{g} / \mathrm{m}^{3}$ ]. Our low levels of ozone are in agreement with the results of other studies from the $1990 \mathrm{~s}$, showing low levels $(<2-20 \mathrm{ppb})$ of ozone $(12,14,44)$. Earlier studies in aircraft have reported higher ozone concentrations in cabin air, typically $200-800 \mathrm{ppb}(46,47)$.

In conclusion, tobacco smoking in commercial aircraft causes a drastic increase in the exposure to respirable particles. This exposure to environmental tobacco smoke may cause irritative symptoms, particularly ocular and general symptoms, impair the perception of cabin air quality, decrease tear-film stability, and alter nasal patency in aircrew members. Our results support the view that, despite the high air exchange rate and efficient air filtration, smoking in commercial aircraft leads to significant pollution in aircraft. It also implies that the measurement of tear-film stability and the use of acoustic rhinometry, in combination with the determination of specific biomarkers in nasal lavage fluid, can be applied in field studies on the medical effects of the cabin environment of aircraft.

\section{Acknowledgments}

This study was partly supported by grants from the Swedish Council for Worklife Research and The Swedish Foundation for Health Care Sciences and Allergy Research.

\section{References}

1. Mendell MJ. Non-specific symptoms in office workers: A review and summary of the epidemiological literature. Indoor Air 1993;3:227-36.
2. Apter A, Bracker A, Hodgson M, Sidman J, Leung WY. Epidemiology of the sick building syndrome. J Allergy Clin Immunol 1994;94:277-_-88.

3. Woodward A. Is passive smoking in the workplace hazardous to health? Scand J Work Environ 1991;7:293-301.

4. Jaakkola JJK, Heinonen OP, Seppänen O. Sick building syndrome, sensation of dryness, and thermal comfort in relation to room temperature in an office building: need for individual control of temperature. Environ Int 1989;15:163-8.

5. Raynal A, Burge PS, Robertson A, Jarvis M, Archibald M, Hawkin D. How much does environmental tobacco smoke contribute to the building symptom index? Indoor Air 1995;5:22-8.

6. Willes SR, Fitzgerald TK, Permutt T, Proud D, Haley NJ, Bascom R. Acute respiratory response to prolonged, moderate levels of sidestream tobacco smoke. J Toxicol Environ Health 1998;53:193-209.

7. Bascom R, Kesavanathan J, Permutt T, Fitzgerald TK, Sauder L, Swift DL. Tobacco smoke upper respiratory response relationships in healthy nonsmokers. Fundam Appl Toxicol 1996;29:86-93.

8. Bascom R, Kesavanathan J, Permutt T, Fitzgerald TK, Cheng $\mathrm{K}-\mathrm{H}$, Swift DL. Sidestream tobacco smoke exposure acutely alters human nasal mucociliary clearance. Environ Health Perspect 1995; 103:1026-30

9. International Civil Aviation Organisation. Annual report of the Council. Montreal: International Civil Aviation Organisation, 1993. Doc 9922.

10. Owe JO. Air transportation In: Brune D, Gerhardsson $G$, Crockford GW, Norbäck D,editors. Major Industries and Occupations. Geneva: International Labour Office, 1997:10725 .

11. Rayman RB. Passenger safety, health and comfort: a review. Aviat Space Environ Med 1997;68:432-40.

12. Crawford WA and Holcomb LC. Environmental tobacco smoke (ETS) in airliners - a health hazard evaluation. Aviat Space Environ Med 1991;62:580-6.

13. Drake JW, Johnson DE. Measurements of certain environmental tobacco smoke components on long-range flights. Aviat Space Environ Med 1990;61:531—42.

14. Eatough DJ, Caka FM, Crawford J, Braithwaite S, Hansen LD, Lewis EA. Environmental tobacco smoke in commercial aircraft. Atmos Environ 1992;26A:2211-18.

15. Lindgren T, Willers $S$, Skarping G, Norbäck D. Urinary cotinine concentration in flight attendants, in relation to exposure to environmental tobacco smoke during intercontinental flights. Int Arch Occup Environ Health 1999;72:475-9.

16. Mattson ME, Boyd G, Byar D, Brown C, Callahan JF, Corle $\mathrm{D}$, et al. Passive smoking on commercial airline flights. JAMA 1989;261:867-72.

17. Nadga NL, Koontz MD, Konheim AG, Hammond SK. Measurement of cabin air quality aboard commercial airliners. Atmos Environ 1992;26A; 2203-10.

18. Oldaker GB III, Condrad FC. Estimation of effect of environmental tobacco smoke on air quality within passenger cabins of commercial aircraft. Environ Sci Technol 1987;21:994 -9.

19. Eng WG. Survey on eye comfort in aircraft: I- Flight attendants. Aviat Space Environ Med 1979;50:401-4.

20. Haugli L, Skogstad A, Hellesøy OH. Health, sleep, and mood perceptions reported by airline crews flying short and long hauls. Aviat Space Environ Med 1994;65:27-34.

21. Reed D, Claser S, Kaldor J. Ozone toxicity symptoms among flight attendants. Am J Ind Med 1980;1:43-54.

22. Tashkin DP, Coulson AH, Simmons MS, Spivey GH. Respi- 
ratory symptoms of flight attendants during high-altitude flight: possible relation to cabin ozone exposure. Int Arch Occup Environ Health 1983;52:117-37.

23. Malm L. Measurement of nasal patency. Allergy 1997;52(suppl 40):19-23.

24. Peden DB. The use of nasal lavage for objective measurement of irritant-induced nasal inflammation. Regul Toxicol Pharmacol 1996;24:76-8.

25. Koren HS, Hatch GE, Graham ED. Nasal lavage as a tool in assessing acute inflammation in response to inhaled pollutants. Toxicology 1990;60:15-25.

26. Wålinder R, Norbäck D, Wieslander G, Smedje G, Erwall C, Venge $P$. Nasal patency and lavage biomarkers in relation to settled dust and cleaning routines in schools. Scand J Work Environ Health 1999;25:137-43.

27. Wieslander G, Norbäck D, Wålinder R, Erwall C, Venge P. Inflammation markers in nasal lavage, and nasal symptoms in relation to relocation to a newly painted building: a longitudinal study. Int Arch Occup Environ Health 1999;72:507-15.

28. Hauser R, Christiani DC. Variability of nasal lavage polymorphonuclear leukocyte counts in unexposed subjects: Its potential utility for epidemiology. Arch Environ Health 1994:49:267-72.

29. Franck C, Bach E, Skov P. Prevalence of objective eye manifestations in people working in office buildings with different prevalences of the sick building syndrome compared with the general population. Int Arch Occup Environ Health 1992;65;65-9.

30. Kjaergaard S. Assessment of eye irritation in humans. Ann NY Acad Sci 1992;641;187—98.

31. Wyon DP. Sick buildings and the experimental approach. Environ Technol 1992;13:313-22.

32. Hocking MB. Indoor air quality: recommendations relevant to aircraft passenger cabins. Am Ind Hyg Assoc J 1998;59:446 54.

33. Norbäck D, Torgen M, Edling C. Volatile organic compounds, respirable dust and personal factors related to prevalence and incidence of sick building syndrome in primary schools. Br J Ind Med 1990;47:733-41.

34. Palmgren U, Ström G, Blomqvist G, Malmberg P (1986). Collection of airborne micro-organisms on Nucleopore filters, estimation and analysis-CAMNEA method. J Appl Bacteriol 1986;61:401-6.

35. Ferm M, Svanberg P-A. Cost-efficient techniques for urbanand background measurements of So2 and No2. Atmos Environ 1998;32:1377-81.
36. Andersson K, Hallgren C, Levin J-O, Nilsson C-A. Chemosorbtion sampling and analysis of formaldehyde in air: influence on recovery during simultaneous sampling formaldehyde, phenol, furfural alcohol. Scand J Work Environ Health 1981;7:282-9

37. Anonymous. Ventilation och luftkvalitet [Ventilation and quality of air]. Stockholm: National Swedish Board of Occupational Safety and Health, 1993. AFS 1993:5 (in Swedish)

38. Venge P, Hällgren R, Stålenheim G, Olsson I. Effects of serum and cations on the selective release of granular proteins from human neutrophils during phagocytosis. Scand J Haematol 1979;22:317-26.

39. Peterson CGB, Nystrand J, Andersson AS, Nilsson L, Venge P. Radioimmunoassay of human eosinophil cationic protein by an improved method: establishment of normal levels in serum turnover in vivo. Clin Exp Allergy 1991;21:561-7

40. Schmekel B, Karlsson SE, Linden K, Sundström C, Tegner H, Venge P. Myeloperoxidase in human lung lavage, I: a marker of local neutrophil activity. Inflammation 1990;14:447-54.

41. Wyon NM, Wyon DP. Measurement of acute response to draught in the eye. Acta Ophthalmol 1987;65:385-92.

42. Norbäck D, Björnsson E, Widström J, Ström G, Edling C, Palmgren U, et al. Asthma and the home environment. In: Sterling E, Bieva C, Collett C, editors. Building design, technology, and occupant well-being in temperate climates. Atlanta (GA): American Society of Heating and Air-conditioning Engineer (ASHRAE), 1993:329-333. ASHRAE special publications 90353

43. Björnsson E, Norbäck D, Janson C, Widström J, Palmgren U, Ström G, Boman G. Asthmatic symptoms and indoor levels of microorganisms and house dust mites. Clin Exp Allergy 1995;25:423-31.

44. O’Donnell A, Donnini G, Nguyen VH. Air quality, ventilation, temperature and humidity in aircraft. ASHRAE $\mathbf{J}$ 1991;33:42-6.

45. Wick RL, Irvine LA. The microbiological composition of airliner cabin air. Aviat Space Environ Med 1995;66:220 - 4.

46. Bischof W. Ozone measurements in jet airliner cabin air. Water, Air Soil Pollut 1973;2:3-14.

47. Nastrom GD, Holdeman JD, Perkins PJ. Measurements of cabin and ambient ozone on B747 airplanes. J Aircr 1980;17:246-9.

Received for publication: 1 November 1999 